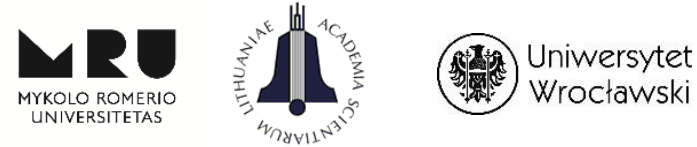

\title{
AN ANALYSIS OF COMMERCIAL RELATIONS BETWEEN LITHUANIA AND SPAIN AFTER THE EUROPEAN UNION'S INTEGRATION
}

\author{
Aurimas RUDŽIONIS \\ Kaunas University of Technology \\ E-mail: aurimas.rudzionis@ktu.lt \\ Antonio MIHI-RAMÍREZ \\ Granada University \\ E-mail: amihi@ugr.es \\ María del Mar HOLGADO-MOLINA \\ Granada University \\ E-mail:mholgado@ugr.es
}

doi:10.13165/IE-14-8-2-05

\begin{abstract}
The commercial relations between European Union and Lithuania has been intensified significantly due to the integration process. This article analyzes the commercial impact of trade barriers removal in Lithuania for its commercial partners, especially in the case of Spain and its European competitors. A comparative analysis of the evolution and singularities of the Spanish's import/export flows to Lithuania from 2000 to 2013 revealed that the international trade between both countries became more active, growing and diverse because of different comparative advantages. Even if the rest of European countries keep a bigger share market, there is no foreseeable risk of trade diversion to the detriment of Spanish products.
\end{abstract}

JEL classification: F1.

Keywords: trade integration, intra-industry trade, comparative advantages, 


\section{Introduction}

The integration in the European Union (EU) leaded toward a commercial liberalization. The mentioned integration process has generated a significant impact on the international trade between Spain and Lithuania through the creation or diversion of trade exchanges, with several advantages or disadvantages for Spanish products.

This research attempts to analyze what impact could generate the SpanishLithuanian trade after tariffs removal, according to the specificities of their international trade. It also compares international exchanges of the main competitors in this market (other EU countries) specifying in which sectors market share in Spain increases or no.

In order to reach this objective, the research begins with a review of the potential repercussions of commercial liberalization that are provided by the theories of international economic integration. According to these, the elimination of trade barriers between member countries encourages a more balanced trade flows (including flows of productive factors) within the integrated area and third countries, which usually also improves the relations between member countries in the detriment of the rest of the world. Trade diversion towards the integrated area is a logical consequence of the reduction of prices of imported products from the member countries instead of from third countries (Bergstrand, 1990). Thus, the domestic products become cheaper because of the disappearance of trade barriers.

After the incorporation of Lithuania into the EU, reorientation of imports, could lead to increased and more diverse exports from Spain to the Lithuanian market. However, imports could remain the same since the EU does not provide changes in the manufacturing business in Lithuania, which is fully liberalized before some decades. Therefore, it is possible that this trade diversion benefits Spain and reverts in correcting the chronic Spanish trade deficit with Lithuania. Similarly, trade creation will generate better results from competition with Lithuanian producers, which could also provide great opportunities in a market with a large number of potential consumers due to industrialization and modernization of the economic structure that requires a significant volume of imports.

Nevertheless, Spain-Lithuania integration could also lead to an increase in exports from other EU countries (Aturupane et al., 1999). However, there is a risk that these markets are most benefited by diversion or creation of trade than the Spanish, it would only happen in the case if Spanish products become less competitive, so for this reason it is analyzed in this article.

Theories of the international trade argue that the results of the integration are closely linked to the market structures (Aiginger, 1997). Thus, to predict the business impact on Spain is necessary to analyze the structure of comparative advantages and disadvantages in Spanish trade with Lithuania. This analysis will let us discern the degree of competitiveness of Spanish exports and the expected impact of free trade on the EU.

In addition, a comparative analysis of the features of Spanish exports to Lithuania is used in order to find out strong and weak points of Spain's main competitors in this market. 
An Analysis of Commercial Relations Between Lithuania and Spain After the European Union's Integration

It will allow us to determine the degree and the type of existing competition (Gabszewicz et al., 1981), as well as to discern the impact of free trade in the EU in Spanish exports.

\section{Specific features of Spanish exports to Lithuania against its European competitors}

The opportunities offered by the incorporation of Lithuania market to the EU are not only a consequence of the trade policy of the EU (Blanes and Martín, 2000). In the case of Spain, it is due to a competition that develops the Spanish economy over other markets that have started in a legitimate struggle in order to greater market share in the Baltic country. Therefore, in order to evaluate the commercial impact generated by trade exchanges to Spain, we need to analyze the Spanish export specialization and the structure of comparative advantages and disadvantages of its trade with Lithuania, i.e., their strengths and weaknesses compared to the mentioned competitive markets.

\section{Commercial significance of each partner}

The analysis of the evolution of the various export flows to Lithuania during the analyzed period, from 2000 to 2013, showed in all cases a significant increase in sales volume. As shown in table 1 and figure 1 and 2, although the average European sales growth is positive and logically higher than in Spain because the EU includes more countries, however an analysis of the annual growth rates of the Spanish sales showed that it is $27.34 \%$ annually since the 2000 s, in comparison with other EU countries $(16,1 \%)$. Therefore, the Spanish exports to Lithuania experienced greater and more intense average annual growth than in rest of the EU, with further growth in the phases of upturns in the business cycle and a further contraction during economic recession in the case of Spain. 
Table 1: Exports to Lithuania from Spain and the UE 2000-2013

\begin{tabular}{|c|c|c|c|c|c|c|c|c|c|c|}
\hline \multicolumn{6}{|c|}{ SPAIN } & \multicolumn{5}{|c|}{ EUROPEAN UNION } \\
\hline year & $\begin{array}{c}\text { Import Value } \\
\text { (thousands of } \\
\text { euros) }\end{array}$ & $\begin{array}{c}\text { Increase of } \\
\text { import in the } \\
\text { period }(\%)\end{array}$ & $\begin{array}{c}\text { Export Value } \\
\text { (thousands of } \\
\text { euros) }\end{array}$ & $\begin{array}{c}\text { Increase of } \\
\text { export in the } \\
\text { period }(\%)\end{array}$ & $\begin{array}{c}\text { Export } \\
\text { Market } \\
\text { shared } \\
(\%)\end{array}$ & $\begin{array}{c}\text { Import Value } \\
\text { (thousands of } \\
\text { euros) }\end{array}$ & $\begin{array}{l}\text { Increase of } \\
\text { import in the } \\
\text { period }(\%)\end{array}$ & $\begin{array}{c}\text { Export Value } \\
\text { (thousands of } \\
\text { euros) }\end{array}$ & $\begin{array}{c}\text { Increase of } \\
\text { export in } \\
\text { the period } \\
(\%)\end{array}$ & $\begin{array}{c}\text { Export } \\
\text { Market } \\
\text { shared } \\
(\%)\end{array}$ \\
\hline 1999 & $41.003,79$ & & 62815,08 & & & $2.101 .683,60$ & & 3266161 & & \\
\hline 2000 & 90041,78 & $120 \%$ & 66811,71 & $6,36 \%$ & $0,05 \%$ & 2850841,93 & $36 \%$ & $4.839 .448,20$ & $48,17 \%$ & $1,32 \%$ \\
\hline 2001 & 166984,57 & $85 \%$ & 150768,26 & $125,66 \%$ & $0,12 \%$ & 3441475,42 & $21 \%$ & $5.612 .790,70$ & $15,98 \%$ & $1,16 \%$ \\
\hline 2002 & 165998,83 & $-1 \%$ & 160565,81 & $6,50 \%$ & $0,12 \%$ & 3594896,86 & $4 \%$ & $6.230 .958,63$ & $11,01 \%$ & $1,10 \%$ \\
\hline 2003 & 190581,24 & $15 \%$ & 112862,04 & $-29,71 \%$ & $0,08 \%$ & 4005190 & $11 \%$ & $6.632 .746,39$ & $6,45 \%$ & $1,08 \%$ \\
\hline 2004 & 98991,34 & $-48 \%$ & 99768,96 & $-11,60 \%$ & $0,07 \%$ & 4780929,12 & $19 \%$ & $8.629 .662,72$ & $30,11 \%$ & $1,47 \%$ \\
\hline 2005 & 181914,96 & $84 \%$ & 129640,20 & $29,94 \%$ & $0,08 \%$ & 5569867,52 & $17 \%$ & $10.689 .924,35$ & $23,87 \%$ & $1,63 \%$ \\
\hline 2006 & 237033,84 & $30 \%$ & 178694,70 & $37,84 \%$ & $0,10 \%$ & 6226075,69 & $12 \%$ & $12.279 .291,53$ & $14,87 \%$ & $1,39 \%$ \\
\hline 2007 & 138569,47 & $-42 \%$ & 324922,79 & $81,83 \%$ & $0,18 \%$ & 7451245,86 & $20 \%$ & $14.015 .780,12$ & $14,14 \%$ & $1,26 \%$ \\
\hline 2008 & 371755,99 & $168 \%$ & 282829,21 & $-12,95 \%$ & $0,15 \%$ & 9114753,52 & $22 \%$ & $16.539 .611,24$ & $18,01 \%$ & $1,48 \%$ \\
\hline 2009 & 194444,83 & $-48 \%$ & 164016,93 & $-42,01 \%$ & $0,10 \%$ & 6732211,33 & $-26 \%$ & $13.060 .596,56$ & $-21,03 \%$ & $1,84 \%$ \\
\hline 2010 & 197047,37 & $1 \%$ & 182655,41 & $11,36 \%$ & $0,10 \%$ & 8884730,48 & $32 \%$ & $16.277 .719,11$ & $24,63 \%$ & $1,79 \%$ \\
\hline 2011 & 274937,78 & $40 \%$ & 219820,33 & $20,35 \%$ & $0,10 \%$ & 11887026,46 & $34 \%$ & $21.469 .656,42$ & $31,9 \%$ & $1,82 \%$ \\
\hline 2012 & 304638,63 & $11 \%$ & 274075,76 & $24,68 \%$ & $0,12 \%$ & 12956872,71 & $9 \%$ & $23.908 .831,01$ & $11,36 \%$ & $1,84 \%$ \\
\hline 2013 & 741979,34 & $144 \%$ & 642688,52 & $134,49 \%$ & $0,33 \%$ & 12775057,81 & $-1 \%$ & $22.923 .099,36$ & $-4,12 \%$ & $1,65 \%$ \\
\hline average & & $40 \%$ & & $27,34 \%$ & & & $15 \%$ & & $16,1 \%$ & \\
\hline
\end{tabular}

Source: Adapted from U.E. Trade Statistics, Ministry of Economics of Spain, Datacomex (2014)

Figure 1: Evolution of the exports growth to Lithuania during $2000-2013$

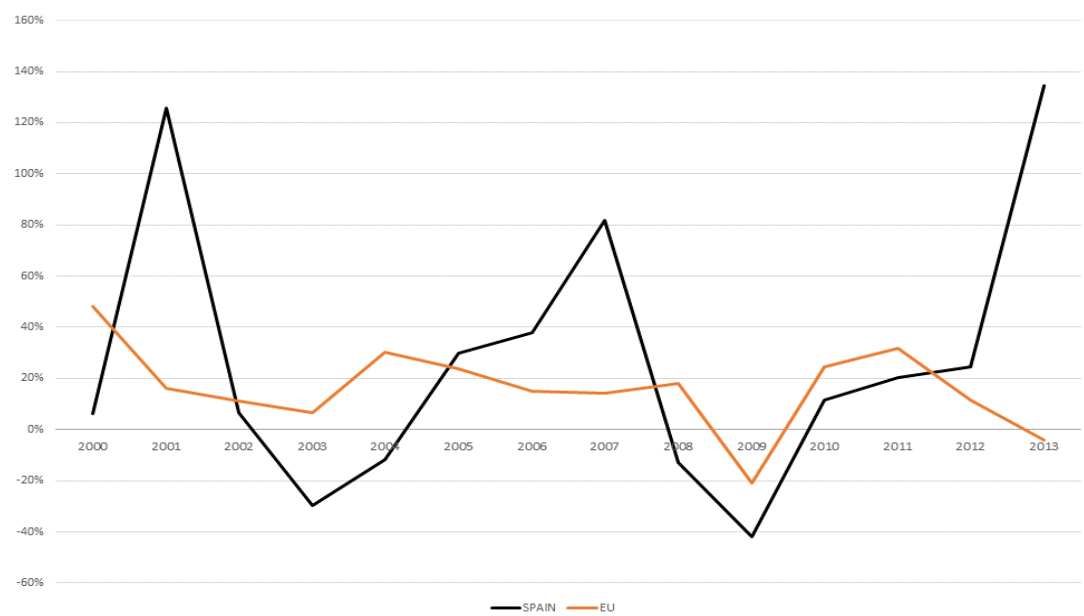

Source: Adapted from U.E. Trade Statistics, Ministry of Economics of Spain, Datacomex (2014) 
An Analysis of Commercial Relations Between Lithuania and Spain After the European Union's Integration

Regarding average growth of imports to Lithuania from Spain, it is much higher the growth of export, $40 \%$ versus $27.34 \%$, and also with respect to the EU, $40 \%$ versus $15 \%$, and has a greater variation in periods of economic expansion (see Table 1 and Figure 2).

Figure 2: Evolution of the imports growth to Lithuania during $2000-2013$

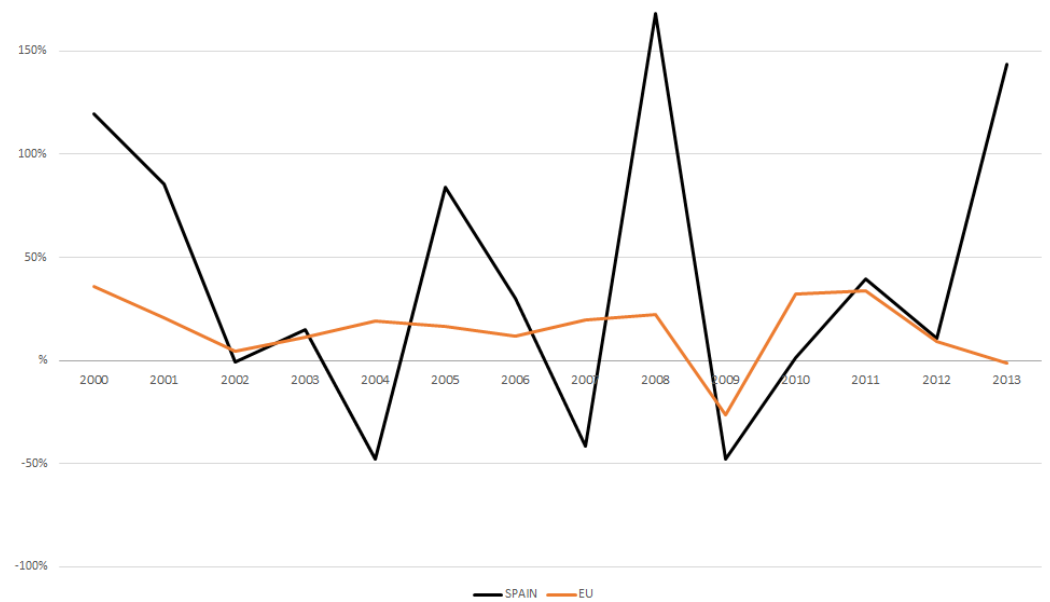

Source: Adapted from U.E. Trade Statistics, Ministry of Economics of Spain, Datacomex (2014)

Although the Spanish market share in the Baltic country has increased, however, in none of these cases has been an increase in the relative significance of Lithuania as a customer. In the case of Spain, the market share represents approximately $0.33 \%$ of the Spanish sales (1.65\% of the EU sales), due to the greater progression experienced by the overall volume of Spanish foreign trade, mainly oriented towards other European partners.

According to the requirements of the theoretical models of integration, since the incorporation of Lithuania into the EU, the Spain-Lithuania trade has been more active than in previous years (although this has not resulted in a significant increase of the market share), contrary to what happened in other European countries as a whole. Maybe this is because the closest countries to Lithuania than to Spain (Russia, Germany, Poland, Latvia, the Netherlands), have reoriented their trade to their geographically closest partner countries. Therefore, taking into consideration the geographical variable, it is expected that these countries will continue to be partners that increase their volume of trade with Lithuania, 
which will be further encouraged by the gradual liberalization of its market. We cannot forget that the geographic factor is one of the variables that influence the intensity of trade between trading partners. In accordance with the proposals of recent international trade models that are grouped under the name "geography and trade models", trade data indicates that geographic proximity stimulates trade, and here Spain do not have the biggest advantage (Helpman and Krugman, 1985).

\section{Strengths of Spain against its European competitors}

Still, it is not prudent to make a prediction without considering other variables. In this regard, it is widely known that countries trade depends on their comparative advantages, this basic concept introduced by David Ricardo justifies international specialization, and, in a general way, is defined by comparing relative prices of different goods in different countries (Balassa and Nolan, 1989). Each country specializes and exports those goods in which the country gets comparatively higher productivity while imports those where the country is relatively less productive. Therefore, the logical counterpart of exports and imports are both sources of profit for the trade.

To explain the structure of comparative advantages of countries many hypotheses are used, among which is the Heckscher-Ohlin-Samuelson (HOS): Disparities in their endowments of productive factors, capital and work (Bergstrand, 1990). According to this model, the response of the elimination of trade barriers linked to the Association Agreement would be the specialization of countries involved in the production and export of goods that intensively use a relative greater productive factor. Therefore, the extension would result in an increase in inter-industry trade (exchange of goods in different sectors).

Although it does not have the necessary data to identify the true sources of comparative advantage of a country as defined by the theory, if it is possible to approximate them by trade data that largely reflects these advantages ${ }^{1}$. It was developed a series of indicators of revealed comparative advantage, following the initial concept of Balassa and Nolan (1989), which provides an overview of the pattern of trade of a country. The index of revealed comparative advantage (RCA) used in this research ${ }^{2}$, refers to the contribution to the

\footnotetext{
${ }^{1}$ Obviously, this is an approximation, since trade flows are influenced by other factors such as trade policy or exchange rate. In this regard, we can specify that our goal is to compare the competitiveness of Lithuanian market of Spanish products with the rest of EU products, thereby altering the type of the trade does not affect the relative competitiveness between different markets of euro area, although it may itself result in the replacement of European imports for most Lithuanian national consumption.

${ }^{2}$ RCA: translates the comparative advantages and disadvantages reflected by the trade between two partners measuring the contribution to the trade balance of each sector (Lafay, 1987). The VCR for sector $\mathrm{j}$ can be estimated by:

$I V C_{j}=(1000 /(X+M))\left(\left(X_{j}-M_{j}\right)-(X-M)\left[\left(X_{j}+M_{j}\right) /(X+M)\right]\right)$ being respectively $\mathrm{X}, \mathrm{Xj}$ and total exports of sector $\mathrm{j}$, and $\mathrm{M}, \mathrm{Mj}$ total imports and the sector $\mathrm{j}$. Considers that trade in a sector $\mathrm{j}$ has a comparative advantage (or disadvantage) if the trade balance is greater (or lower) than the reference balance, and this is where you obtain to distribute the country's total trade balance between all sectors according to their relative weight in total trade. Thus, its contribution to the trade balance is the difference between the actual balance and the theoretical balance. A positive (negative) contribution is interpreted as a revealed comparative advantage (disadvantage) for this sector.
} 
An Analysis of Commercial Relations Between Lithuania and Spain After the European Union's Integration

bilateral trade balance between each sector expressed in terms of bilateral trade volume unlike other alternative indices which refer to the data on total trade of a country relative to GDP.

Therefore, the rate used reflects the pattern of bilateral trade, but do not boast the strengths or weaknesses of an economy in general. Thus, we calculated the RCA for all Spanish trade (Table 2) and the EU as a reference for the study of the specialization profile of Spain in its trade with Lithuania.

Table 2: Intensity of the comparative advantage / disadvantage revealed from Spain in its trade with Lithuania, 2000 -2013

\begin{tabular}{|l|l|l|l|}
\hline \multicolumn{2}{|c|}{$\begin{array}{c}\text { Moderated revealed comparative } \\
\text { disadvantage (between 0 and -30\%) }\end{array}$} & \multicolumn{2}{c|}{$\begin{array}{c}\text { High revealed comparative } \\
\text { disadvantage } \\
\text { (lower than -30 \%o) }\end{array}$} \\
\hline $\begin{array}{l}\text { Miscellaneous manufactured } \\
\text { articles }\end{array}$ & -23.79 & Mineral products & -194.49 \\
\hline $\begin{array}{l}\text { Optical, photographic, } \\
\text { cinematographic, measuring, } \\
\text { checking, precision, medical or } \\
\text { surgical instruments and } \\
\text { apparatus }\end{array}$ & -4.54 & $\begin{array}{l}\text { Base metals and articles } \\
\text { of base metal }\end{array}$ & -36.74 \\
\hline Live animals; animal products & -3.43 & & \\
\hline $\begin{array}{l}\text { Wood and articles of wood; wood } \\
\text { charcoal; cork and articles of } \\
\text { cork; manufactures of straw, of } \\
\text { esparto or other plaiting } \\
\text { materials; basket ware and } \\
\text { wickerwork. }\end{array}$ & -1.65 & & \\
\hline $\begin{array}{l}\text { Raw hides and skins, leather, fur } \\
\text { skins and articles because of that; } \\
\text { saddlery and harness; travel } \\
\text { goods, handbags, and similar } \\
\text { containers; articles of animal gut }\end{array}$ & -0.61 & & \\
\hline $\begin{array}{l}\text { Works of art, collectors' pieces, } \\
\text { and antiques }\end{array}$ & -0.16 & & \\
\hline $\begin{array}{l}\text { Moderated revealed comparative } \\
\text { advantage (between 0 and 30\%o) }\end{array}$ & & & \\
\hline
\end{tabular}




\begin{tabular}{|c|c|c|c|}
\hline Vegetable products & 25.39 & $\begin{array}{l}\text { Machinery and } \\
\text { mechanical appliances; } \\
\text { electrical equipment; parts } \\
\text { because of that; sound } \\
\text { recorders and } \\
\text { reproducers, television } \\
\text { image and sound } \\
\text { recorders and } \\
\text { reproducers, and parts and } \\
\text { accessories of such } \\
\text { articles }\end{array}$ & 76.57 \\
\hline $\begin{array}{l}\text { Vehicles, aircraft, vessels and } \\
\text { associated transport equipment }\end{array}$ & 24.96 & $\begin{array}{l}\text { Prepared foodstuffs; } \\
\text { beverages, spirits, and } \\
\text { vinegar; tobacco }\end{array}$ & 45.31 \\
\hline $\begin{array}{l}\text { Commodities that are classified } \\
\text { according special requirements }\end{array}$ & 22.93 & & \\
\hline $\begin{array}{l}\text { Articles of stone, plaster, cement, } \\
\text { asbestos, mica or similar } \\
\text { materials; ceramic products; glass } \\
\text { and glassware }\end{array}$ & 15.91 & & \\
\hline $\begin{array}{l}\text { Products of the chemical or allied } \\
\text { industries }\end{array}$ & 15.67 & & \\
\hline Textiles and textile articles & 6.13 & & \\
\hline $\begin{array}{l}\text { Plastics and articles because of } \\
\text { that; rubber and similar }\end{array}$ & 5.65 & & \\
\hline $\begin{array}{l}\text { Footwear, headgear, umbrellas, } \\
\text { sun umbrellas, walking-sticks, } \\
\text { seat-sticks, whips, riding-corps } \\
\text { and parts because of that; } \\
\text { prepared feathers and articles } \\
\text { made in addition to that; artificial } \\
\text { flowers; articles of human hair }\end{array}$ & 4.45 & & \\
\hline $\begin{array}{l}\text { Pulp of wood or other fibrous } \\
\text { cellulosic material; recovered } \\
\text { paper or paperboard; paper and } \\
\text { paperboard and articles because } \\
\text { of that }\end{array}$ & 2.61 & & \\
\hline $\begin{array}{l}\text { Natural or cultured pearls, } \\
\text { precious or semi-precious stones, } \\
\text { precious metals, metals clad with } \\
\text { precious metal, and articles } \\
\text { because of that; imitation jewelry; } \\
\text { coin }\end{array}$ & 0.12 & & \\
\hline
\end{tabular}

Source: Calculated from U.E. Trade Statistics, Ministry of Economics of Spain, Datacomex 
An Analysis of Commercial Relations Between Lithuania and Spain After the European Union's Integration

A comparative examination of the structure of the advantages and disadvantages of trade in Spain in the Lithuanian market, initially shows that Spain has a very high comparative advantage in Machinery and mechanical appliances sections; electrical equipment; parts thereof; sound recorders and reproducers, television image and sound recorders and reproducers, and parts and accessories of Such articles; and to a lower extent in the sectors: Prepared foodstuffs; beverages, spirits and vinegar; tobacco (Table 2). Therefore, there is no foreseeable risk of trade diversion to the detriment of Spanish products for the rest of the EU in these sections, which represents around $15 \%$ of Spanish exports to Lithuania (Datacomex, 2014).

Figure 3: Spain's comparative advantage in trade with Lithuania during $2000-2013^{3}$

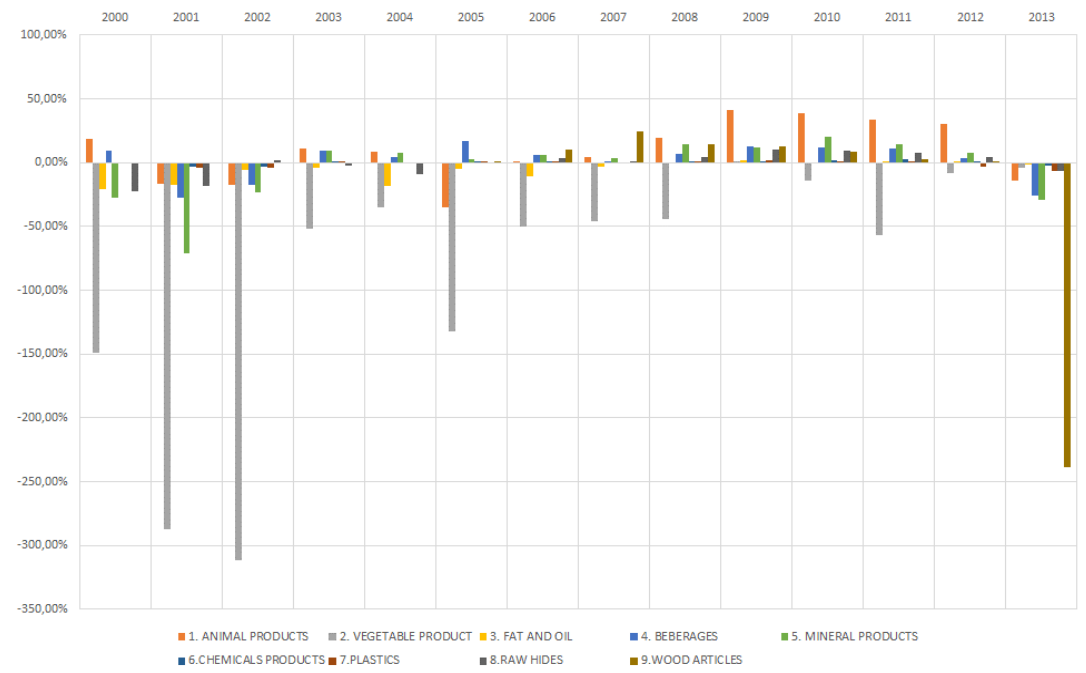

Source: Calculated from U.E. Trade Statistics, Ministry of Economics of Spain, Datacomex (2014)

In the case of animal's products, Prepared foodstuffs; beverages, spirits and vinegar; travel goods, handbags and similar containers; articles of the animal gut, as Figure 3 and 4

${ }^{3}$ Sections: 1 Live animals; animal products; 2 Vegetable products; 3 Animal or vegetable fats and oils and their cleavage products; prepared edible fats; animal or vegetable waxes; 4 Prepared foodstuffs; beverages, spirits and vinegar; tobacco; 5 Mineral products; 6 Products of the chemical or allied industries; 7 Plastics and articles thereof; rubber and articles thereof; 8 Raw hides and skins, leather, fur skins and articles thereof; saddlery and harness; travel goods, handbags and similar containers; articles of animal gut; 9 Wood and articles of wood; wood charcoal; cork and articles of cork; manufactures of straw, of esparto or of other plaiting materials; basket ware and wickerwork 
shows, in the analyzed period Spain has greater advantage than other European countries that trade with Lithuania. However, this may be because many European companies are developing outsourcing contracts primarily with the Eastern countries, keeping their margins in the phases of trade (Aturupane et al., 1999). Gradually, the EU has developed this strategy as well as a specialization in higher quality products, design, etc. to slow the inevitable decline of an industry that do not require well-qualified labor force and therefore is an interesting market to countries with lower labor costs as Lithuania (Grossman and Helpman, 1991).

Figure 4: UE's comparative advantage in trade with Lithuania during 2000 -2013

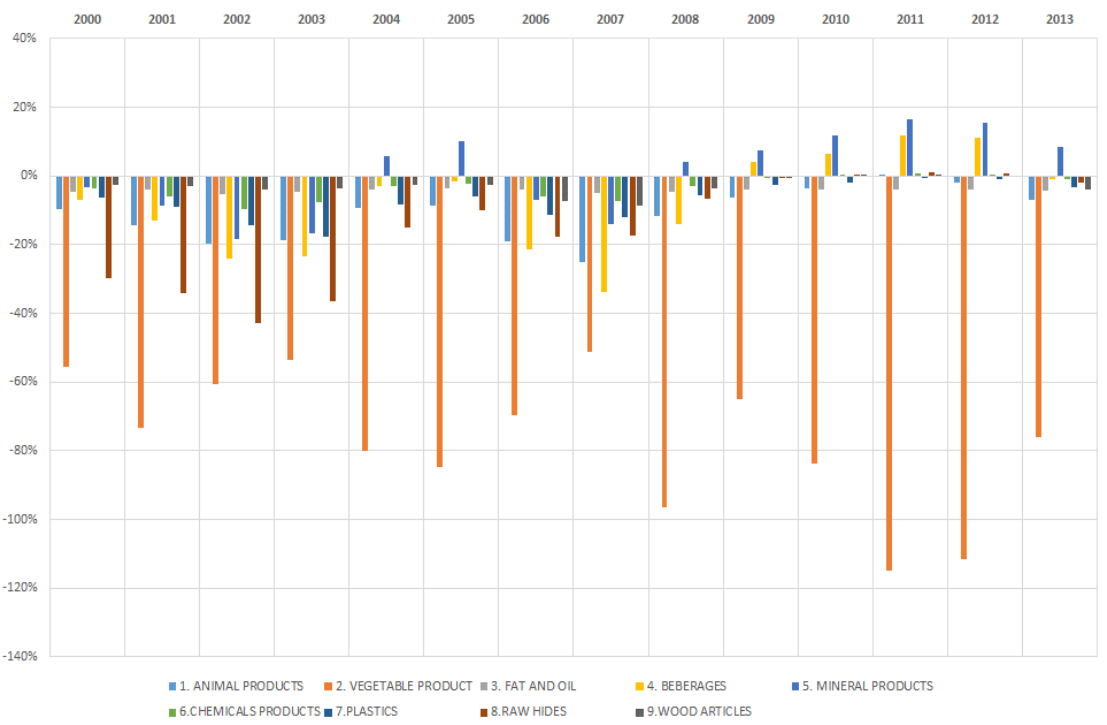

After the incorporation of Lithuania into the EU, the progressive elimination of restrictions on trade in Lithuania regarding its EU imports, can generate a reorientation of their purchases to other European markets. This reorientation can be managed towards the countries in those sections where the comparative advantage is greater than the Spanish. This risk is higher for Mineral products, Base metals and articles of base metal.

\section{Conclusion}

After several years of integration, trade liberalization in Lithuania is a good opportunity for Spain if the products take advantage of their potential or, opposite, may lead to loss of market share in benefit of other EU countries. 
An Analysis of Commercial Relations Between Lithuania and Spain After the European Union's Integration

Theories of the international trade argue that the results of the integration are closely linked to market structures, and these are reflected in the nature of commercial. In light of the analysis of the changing patterns of Spanish exports to Lithuania and its comparison with trade flows from the rest of the EU, we can argue that Spain seems to be able to increase its export share in Lithuania on certain products. In fact, Spanish sales are recording a higher growth than its European competitors. Despite the significant growth of Spanish exports, the importance of Spain as the Lithuanian supplier is still insignificant.

The Spanish specialization profile is different from the whole of the EU, as evidenced by the indicator of comparative advantage. The sectors that positively contribute to the Spanish trade balance with Lithuania are mainly these sectors: Machinery and mechanical appliances; electrical equipment; parts thereof; sound recorders and reproducers, television image and sound recorders and reproducers, and parts and accessories of such articles; while the whole EU records advantages in the most capital-intensive industries. In addition, the evolution of the export specialization index shows that this situation tends to increase. Therefore, there is no foreseeable risk of trade diversion to the detriment of Spanish products and for the rest of the EU in these sectors, which implies around $15 \%$ of Spanish exports to Lithuania; on the contrary, Spain maintains a dominant position that could increase its market share. However, those countries geographically closer to Lithuania still keep a bigger share market because of a reorientation of their trade.

Sections with greater potential risks are: "Mineral products" and "Base metals and articles of base metal" where Spain has a lower advantage.

\section{References}

1. Aiginger, K. (1997). The use of unit values to discriminate between price and quality competitions, Cambridge Journal of Economics, 21: 571-592.

2. Aturupane, C., Djankov, S. and Hoekman, B. (1999). Horizontal and vertical intraindustry trade between Eastern Europe and the European Union, Weltwirtschaftliches Archiv, 135(1): 62-81.

3. Balassa, B. and Nolan, M. (1989). Revealed comparative advantage in Japan and the United States, Journal of International Economic 27, 4(2): 8-22.

4. Bergstrand, J. H. (1990). The Heckscher-Ohlin-Samuelson Model, The Linder Hypothesis and the Determinants of Bilateral Intra-Industry Trade, The Economic Journal, 100 (403): 1 216-1229.

5. Blanes, J. V. and Martín, C. (2000): "The Nature and Causes of Intra-Industry Trade: Back to the Comparative Advantage Explanation? The Case of Spain, Weltwirtschaftliches Archiv, 136(3): 423-441.

6. Gabszewicz, J., Shaked, A. and Sutton, J. (1981). International Trade in Differentiated Products, International Economic Review, 22(3): 527-534. 
7. Helpman, E. and Krugman, P.R. (1985). Market Structure and Foreign Trade: Increasing Returns, Imperfect Competition and International Economy, Cambridge: MIT Press.

8. E.U. Trade Statistics, Ministry of Economics of Spain, Datacomex (2014). Retrieved June 23, 2014 from http://datacomex.comercio.es/

\section{About the Authors:}

Aurimas RUDŽIONIS - Kaunas University of Technology (Lithuania), Faculty of Economics and Management, MSc in Business.

Research interests: economics and international migration.

Antonio MIHI-RAMÍREZ - Granada University, Faculty of Economics and Management,

Department of International and Spanish Economics, $\mathrm{PhD}$.

Research interests: economics and international migration.

María del Mar HOLGADO-MOLINA - Faculty of Economics and Business Administration. Campus Cartuja.

Research interests: economics. 